\title{
Challenges for Methods of Teaching English Vocabulary to Non-native Students
}

\author{
Omer Elsheikh Hago Elmahdi \\ Open University of the Sudan, Sudan \\ Abdulrahman Mokbel Mahyoub Hezam
Department of Languages and Translation,
Faculty of Science and Arts, Taibah University, Saudi Arabia
}

ABSTRACT

This study is meant to have a through argument about the main topic of this research, which is the challenges of teaching methods of English vocabulary to non-native students. The researchers try to introduce a conceptual coverage of certain areas that are relevant to English vocabulary teaching / learning. This conceptual coverage includes: the definition of the term vocabulary, kinds of vocabulary, the importance of vocabulary, general principles for successful vocabulary teaching, teaching vocabulary in the English as a foreign language (EFL) context is challenging, techniques of teaching vocabulary, and the need for teaching vocabulary. Among the qualitative methods the researchers chose the record keeping method. This method makes use of the already existing reliable documents and similar sources of information as the data source. This data can be used in a new research. The researchers have collected a number of relevant studies and quarrying critically and deeply in these studies to signal out the Challenges for Methods of Teaching English Vocabulary to Non-native Students. Qualitative data collection allows collecting data that is non-numeric and helps us to explore how decisions are made and provide a detailed insight. For reaching such conclusions the data that is collected should be holistic, rich and nuanced and findings to emerge through careful analysis. This is why the researchers have examined and collected many relevant references, case studies that deal with teaching vocabulary. To carry out this research the researchers have introduced certain questions and surveyed a huge number of previous studies after covering the relevant literature. Finally, the challenges that are critically obtained by the researchers are classified into three main categories. The first category, challenges related to students, the second one, challenges related to teachers, and the third one, challenges related to methods/techniques/ strategies of teaching vocabulary.

\section{INTRODUCTION}

Introduction Vocabulary learning is often perceived as boring by learners, especially for those who grew up in the digital age. Vocabulary is critical to student learning and in the traditional English classroom, vocabulary has its weaknesses in approach. These included factors such as exposing the 
students only once to meanings and usages of the words, assessing only spelling and not meanings and usages (Sagmiller, 2002).

Allen (1983), introduces some basic issues of vocabulary teaching and learning, and lays a foundation for teaching English vocabulary to beginning-level students. She makes the astute point that although students and teachers alike often think of vocabulary words as something that can be simply translated and memorized, this is not always the case. Learning vocabulary, she insists, requires more than a dictionary. Vocabulary is a cultural phenomenon as well as a linguistic one, and Ms. Allen points out that students must learn the social meanings of words in a foreign language, not just the equivalent word in their native tongue. She mentions that students' success in learning vocabulary depends to a certain extent on the number of senses used in the classroom. One reason that students need encouragement through various sensory activities is that in most cases, foreign language students already have "satisfactory" words in their own language for the vocabulary they are trying to learn in class; therefore, the foreign language student needs some sort of motivation to make him desire to learn foreign words.

It is believable that vocabulary plays an important role in language use. It is the core of language skills. More significantly, it appears to function as a basis for communication, reflection of social reality, emotion promoter, and academic ability predictor. Besides, receptive and productive vocabularies, and active and passive vocabulary according to previous studies have various contributions to language skill performances. Furthermore, values of teaching vocabulary, scope and deepness, and teaching and learning vocabulary materials appear to be associated with student's vocabulary mastery.

\section{The Aims}

This paper aims to:

1. define the term vocabulary,

2. highlight the importance of vocabulary learning as an essential part in foreign language learning,

3. reflect on principles of teaching vocabulary,

4. review the trends in the area of teaching vocabulary through various techniques ESL/EFL teachers use when teaching,

5. explain the kind of vocabulary teaching strategies do the teachers employ,

6. reflecting on methods of Teaching English Vocabulary Non-native Students, and

7. Challenges for Methods of Teaching English Vocabulary to Non-native Students.

\section{RESEARCH PROBLEM}

To have a soft landing to the main topic of this research, which is the challenges of teaching methods of English vocabulary to non-native students, there should a conceptual coverage of certain areas that are relevant to English vocabulary teaching / learning. So, the conceptual coverage includes: the definition of the term vocabulary, kinds of vocabulary, the importance of vocabulary, general principles for successful vocabulary teaching, teaching vocabulary in the English as a foreign language (EFL) context is challenging, techniques of teaching vocabulary, and the need for teaching vocabulary. To carry out this research the researchers have introduced certain questions and surveyed a huge number of previous studies after covering to the relevant literature. 
Elhamdi, O. E. H., \& Hezam, A. M. M. (2020) Challenges for Methods of Teaching English Vocabulary to Non-native Students. Advances in Social Sciences Research Journal, 7(5) 556-575.

\section{Research Questions}

1. What is the importance of vocabulary learning as an essential part in foreign language learning?

2. What are the principles of teaching vocabulary?

3. What are the techniques of teaching vocabulary?

4. What kind of vocabulary teaching strategies do the teachers employ?

5. What are the Methods of Teaching English Vocabulary to Non-native Students?

6. What are the Challenges for Methods of Teaching English Vocabulary to Non-native Students?

\section{Research Method}

As a common fact, qualitative research methods are designed in a manner that they help reveal the behavior and perception of a target audience with reference to a particular topic. There are different types of qualitative research methods like an in-depth interview, focus groups, ethnographic research, content analysis, case study research that are usually used. The results of qualitative methods are more descriptive and the inferences can be drawn quite easily from the data that is obtained. The following are the qualitative research methods that are frequently used: One-on-One Interview, focus groups, ethnographic research, case study research, process of observation, and record keeping. Among these quantitative methods the researchers chose the record keeping method. This method makes use of the already existing reliable documents and similar sources of information as the data source. This data can be used in a new research. This is similar to going to a library. There one can go over books and other reference material to collect relevant data that can likely be used in the research. The researchers have collected a number of relevant studies and quarrying critically and deeply in these studies to signal out the Challenges for Methods of Teaching English Vocabulary to Non-native Students.

\section{Qualitative Data Collection}

Qualitative data collection allows collecting data that is non-numeric and helps us to explore how decisions are made and provide us with detailed insight. For reaching such conclusions the data that is collected should be holistic, rich and nuanced and findings to emerge through careful analysis. This is why the researchers have examined and collected many relevant references, case studies that deal with teaching vocabulary, and abstracts.

\section{The Definition of Vocabulary}

\section{LITERATURE REVIEW}

Vocabulary can be defined as "words we must know to communicate effectively; words in speaking (expressive vocabulary) and words in listening (receptive vocabulary)" (Neuman \& Dwyer, 2009, p. 385). Hornby (1995) defines vocabulary as "the total number of words in a language; vocabulary is a list of words with their meanings". While Ur (1998) states: "Vocabulary can be defined, roughly, as the words we teach in the foreign language. However, a new item of vocabulary may be more than just a single word: for example, post office, and mother-in-law, which are made up of two or three words but express a single idea. A useful convention is to cover all such cases by talking about vocabulary "items" rather than "words. "In addition, Burns (1972) defines vocabulary as" the stock of words which is used by a person, class or profession. Furthermore, Diamond and Gutlohn (2006) state that vocabulary is the knowledge of words and word meanings." From the definitions above, 
it can be concluded that vocabulary is the total number of words that are needed to communicate ideas and express the speakers' meaning. That is the reason why it is important to learn vocabulary.

\section{Kinds of Vocabulary}

Generally, vocabulary can be divided into two types: active and passive vocabulary. Harmer (1991) distinguishes between these two types of vocabulary. The first type of vocabulary refers to the one that the students have been taught and that they are expected to be able to use. Meanwhile, the second one refers to the words which the students will recognize when they meet them, but which they will probably not be able to pronounce. Haycraft, quoted by Hatch and Brown (1995), indicate two kinds of vocabulary, namely receptive vocabulary and productive vocabulary.

\section{Receptive Vocabulary}

Receptive vocabulary is the amount of words that learners recognize and understand when they are used in context, but which they cannot produce. It is vocabulary that learners recognize when they see or meet in reading text but do not use it in speaking and writing (Stuart Webb, 2009).

\section{Productive Vocabulary}

Productive vocabulary is the words that the learners understand and can pronounce correctly and use constructively in speaking and writing. It involves what is needed for receptive vocabulary plus the ability to speak or write at the appropriate time. Therefore, productive vocabulary can be addressed as an active process, because the learners can produce the words to express their thoughts to others (Stuart Webb, 2005).

\section{The Importance of Vocabulary}

According to Zimmerman cited in Coady and Huckin (1998) 'vocabulary is central to language and of critical importance to the typical language learning. It seems that vocabulary is an important part of the English teaching process. It is supposed to be a very effective communicative device as it carries the highest level of importance within peoples' verbal interaction. The importance of vocabulary learning also poses some challenges for teachers. They like to know in what ways instructional programs might foster the acquisition of so many words. Also, one can say that being proficient in English language depends on the knowledge of its vocabulary possessed by the second and foreign language learners and even the native speakers. Though developing the vocabulary is dynamic, it poses several problems, particularly, to non-native students of English. Students with a low vocabulary knowledge tend to show weak academic performance in courses related to language skills, linguistics, literature, and translation at tertiary level.

\section{General Principles for Successful Vocabulary Teaching}

As for principles of teaching English vocabulary, an account for what vocabulary forms need to teach and the principles of how they are taught is vital. It is certain to consider the vocabulary aspects to teach, for it's separately from the vocabulary teaching which in line with its objectives and students' need. To realize it, Nation (2001) proposed these aspects, namely spoken form, written form, parts of word, concept a word has and items it may associate, association of the word, grammar of the word, collocation of the word, register and frequency of the word.

Recent research indicates that teaching vocabulary may be problematic because many teachers are not confident about the best practice in vocabulary teaching and at times do not know where to 
Elhamdi, O. E. H., \& Hezam, A. M. M. (2020) Challenges for Methods of Teaching English Vocabulary to Non-native Students. Advances in Social Sciences Research Journal, 7(5) 556-575.

begin to form an instructional emphasis on word learning (Berne \& Blachowicz, 2008). Teaching words is a crucial aspect in learning a language as languages are based on words (Thornbury, 2002). It is almost impossible to learn a language without words; even communication between human beings is based on words. Both teachers and students agree that acquisition of the vocabulary is a central factor in teaching a language (Walters, 2004). Teaching vocabulary is one of the most discussed parts of teaching English as a foreign language. When the teaching and learning process takes place, problems would appear to the teachers. They have problems of how to teach students in order to gain satisfying results. The teacher should prepare and find out the appropriate techniques, which will be implemented to the students. A good teacher should prepare himself or herself with various and up-to-date techniques. Teachers need to be able to master the material in order to be understood by students, and make them interested and happy in the teaching and learning process in the classroom. The teachers should be concerned that teaching vocabulary is something new and different from student's native language. They also have to take into account that teaching English for young learners is different from adults. The teachers have to know the characteristics of his \her learners. They more over need to prepare good techniques and suitable material in order to gain the target of language teaching.

However, many theories about vocabulary learning process were written, it still remains the matter of memory. Thus, there are several general principles for successful teaching, which are valid for any method. According to Wallace, 1988 the principles are: - aim - what is to be taught, which words, how many - need - target vocabulary should respond students' real needs and interests - frequent exposure and repetition - meaningful presentation - clear and unambiguous denotation or reference should be assured Learning vocabulary is a complex process. The students' aim to be reached in learning vocabulary process is primarily their ability to recall the word at will and to recognize it in its spoken and written form. Generally, knowing a word involves knowing its form and its meaning at the basic level. In deeper aspects it means the abilities to know its (Harmer 1993): 1) Meaning, i.e. relate the word to an appropriate object or context 2) Usage, i.e. knowledge of its collocations, metaphors and idioms, as well as style and register (the appropriate level of formality), to be aware of any connotations and associations the word might have 3) Word formation, i.e. ability to spell and pronounce the word correctly, to know any derivations (acceptable prefixes and suffixes), 4) Grammar, i.e. to use it in the appropriate grammatical form. However, language itself is not only individual lexemes put together, but it is necessary to follow a set of grammar rules to assure correct comprehension of speaker's intention. Therefore, vocabulary together with grammar rules acquisition plays significant role in foreign language teaching.

Teaching vocabulary in the English as a foreign language (EFL) context is challenging. Incidental vocabulary learning is limited due to a lack of second language (L2) input, and most words are learned through classroom instruction. Overall, research has shown marginal L2 vocabulary growth in many EFL situations. Such research indicates a need for a more effective and efficient approach to teaching vocabulary in the EFL context. This chapter discusses how to optimise vocabulary learning in the EFL context. It touches on the following questions: Which words should be taught? How should vocabulary be taught? How many words do EFL learners need to know? What should a vocabulary-learning programme include? How can vocabulary learning be fostered given limited classroom time? Which activities might be useful in indirect vocabulary learning The most important principles of vocabulary teaching identified by the teachers were teaching useful vocabulary which students can use in an authentic context. Mixing explicit and incidental way of 
teaching vocabulary has often been implied to result in more successful learning results (Schmitt 2010) than focusing on one or the other and Finnish teachers of English follow along this view in their teaching of vocabulary.

\section{Techniques of teaching vocabulary}

Here are some techniques of teaching vocabulary as stated by Brewster, Ellis, and Girard (1992).

\section{Using Objects}

Using this technique includes the use of realia, visual aids, and demonstration. They can function to help learners in remembering vocabulary better, because our memory for objects and pictures is very reliable and visual techniques can act as cues for remembering words. In addition, Gairns \& Redman (1986) state that real objects technique is appropriately employed for beginners or young learners and when presenting concrete vocabulary. Objects can be used to show meanings when the vocabulary consist of concrete nouns. Introducing a new word by showing the real object often helps learners to memorize the word through visualization. Objects in the classroom or things brought to the classroom can be used.

\section{Drawing Objects}

can either be drawn on the blackboard or drawn on flash cards. The latter can be used again and again in different contexts if they are made with cards and covered in plastic. They can help young learners easily understand and realize the main points that they have learned in the classroom.

\section{Using Illustrations and Pictures}

Pictures connect students' prior knowledge to a new story, and in the process, help them learn new words. There are plenty of vocabularies that can be introduced by using illustrations or pictures. They are excellent means of making the meaning of unknown words clear. They should be used as often as possible. The list of pictures includes: posters, flashcards, wall charts, magazine pictures, board drawings, stick figures and photographs. Pictures for vocabulary teaching come from many sources. Apart from those drawn by the teacher or students, they are sets of colourful pictures intended for schools. Pictures cut out of newspapers and magazines are very useful as well. Nowadays many readers, vocabulary books and coursebooks contain a vast number of attractive pictures that present the meaning of basic words. The teacher can use learning materials provided by the school. They can also make their own visual aids or used pictures from magazines. Visual support helps learners understand the meaning and helps to make the word more memorable.

\section{Contrast}

Some words are easily explained to learners by contrasting it with its opposite, for instance, the word" good" contrasted with the word "bad". But some words are not. It is almost impossible to contrast the words whose opposite is the gradable one. When the word "white" is contrasted with the word "black", there is an "in between" word" grey". Furthermore, verb "contrast" means to show a difference, like photos that reveal how much weight someone lost by contrasting the "before" and "after" shots Many more studies have also shown that vocabulary is best acquired if it is similar to what is already learnt (e.g. Rudska et al., 1982, 1985), it is not surprising that learning synonyms is a way to expand our vocabulary. Learning about synonyms is important also because this is how dictionaries are organised. Putting bilingual dictionaries aside, mono-lingual dictionaries essentially use words to explain words, and in this process, synonyms are often used (Ilson, 1991). 
Elhamdi, O. E. H., \& Hezam, A. M. M. (2020) Challenges for Methods of Teaching English Vocabulary to Non-native Students. Advances in Social Sciences Research Journal, 7(5) 556-575.

\section{Enumeration}

An enumeration is a collection of items that is a complete, ordered listing of all of the items in that collection. It can be used to present meaning. In other words, this technique helps when any word is difficult to explain visually. We can say "clothes" and explain this by enumerating or listing various items. Teacher may list a number of clothes e.g. a dress, a skirt, trousers etc., and then the meaning of the word "clothes" will become clear. The same is true of 'vegetable' or "furniture", 'for example (Harmer 1991).

\section{Mime, Expressions and Gestures}

Klippel (1994) implies that "mime or gesture is useful if it emphasizes the importance of gestures and facial expression on communication. At the essence it can not only be used to indicate the meaning of a word found in reading passage, but also in speaking activity as it stresses mostly on communication. Many words can be introduced through mime, expressions, and gestures. For example, adjectives: "sad"," happy"; mime and taking a hat off your head to teach hat and so on. Several studies have emphasised the role of gestures in second language (L2) acquisition (Gullberg, 2008). Teachers tend to gesture a lot (Sime, 2001; Hauge, 1999), especially when addressing young learners and/or beginners. It is commonly acknowledged that "teaching gestures" capture attention and make the lesson more dynamic. Using analyses of video recordings of English lessons to French students, Tellier (2007) determined three main roles for teaching gestures: management of the class (to start/end an activity, to question students, request silence, etc.), evaluation (to show a mistake, to correct, to congratulate, etc.) and explanation to give indications on syntax, underline specific prosody, explain new vocabulary, etc.). Teaching gestures appear in various shapes: hand gestures, facial expressions, pantomime, body movements, etc. They can either mime or symbolise something and they help learners to infer the meaning of a spoken word or expression, providing that they are unambiguous and easy to understand. This teaching strategy is thus relevant for comprehension (Tellier, 2007). However, its utility may depend on the kind of gesture used by the teacher. It has been highlighted that foreign emblems, for instance, may lead to misunderstandings when it is not known by the learners (Hauge, 1999; Sime, 2001). In addition to supporting comprehension, teaching gestures may also be relevant for learners' memorisation process. Indeed, many second language teachers who use gestures as a teaching strategy declare that they help learners in the process of memorising the second language lexicon. Many of them have noticed that learners can retrieve a word easily when the teacher produces the gesture associated with the lexical item during the lesson. Others have seen learners (especially young ones) spontaneously reproducing the gesture when saying the word. The effect of gestures on memorisation is thus something witnessed by many but hardly explored on a systematic and empirical basis (Tellier, 2008).

\section{Guessing from Context}

Guessing from context as a way of dealing with unfamiliar vocabulary in unedited selections has been suggested widely by L1 and L2 reading specialists (Dubin, 1993). Nation and Coady (1988) claim that there are two types of contexts. The first type is the context within the text, which includes morphological, semantic and syntactic information in a specific text, while the second one is the general context, or non-textual context, which is the background knowledge the reader has about the subjects be in grid. Williams (1985) agrees with Nation and Coady in considering the specific context as "the other words and sentences that surround that word.... it follows that other words in the context of the unfamiliar word often 'throw light on' its meaning. These other words can be 
found in the sentence containing the unknown word or other sentences beyond the sentence of the unknown item. Similarly, McCarthy (1988) sees context as within the text itself i.e. the morphological, syntactic, and discourse information, which can be classified and described in terms of general features. Learning from context not only includes learning from extensive reading, but also learning from taking part in a conversation, and learning from listening to stories, films, television or the radio (Nation, 2001). In order to activate guessing in a written or spoken text, there should be four elements available: the reader, the text, unknown words, and clues in the text including some knowledge about guessing. The absence of one of these elements may affect the learner's ability to guess. Furthermore, this technique encourages learners to take risks and guess the meanings of words they do not know as much as possible. This will help them build up their selfconfidence so that they can work out the meanings of words when they are on their own. There are many clues learners can use to establish meanings for themselves, such as illustrations, similarity of spelling or sound in the mother tongue, and general knowledge (Walters, 2004).

\section{Eliciting}

This technique is more motivating and memorable by simply giving pupils a list of words to learn.

\section{Translation}

Even though translation does not create a need or motivation of the learners to think about word meaning (Cameron, 2001), in some situations translation could be effective for teachers, such as when dealing with incidental vocabulary (Thornbury, 2002), checking students' comprehension, and pointing out similarities or differences between first and second language, when these are likely to cause errors (Takač, 2008). There are always some words that need to be translated and this technique can save a lot of time.

\section{Teaching Vocabulary}

The teaching of vocabulary definitely is needed but there are as many opinions on how to do it as there are teachers. While explicit teaching of vocabulary is more likely to conclude in successful vocabulary retention than incidental way of teaching, it is highly time-consuming and can cover only a scratch of the vocabulary in the English language (Schmitt 2010). Teachers who in general should have great autonomy, are in a key position when it comes to deciding what and how vocabulary is presented to students inside classrooms.

Knowing a word includes both receptive and productive skills (Melka 1997, McCarthy 1998) in their opinions. The teachers also mentioned several of the different constraints presented by Nation (1990) and Ringbom (1991) but did not include the associative constraints in it. However, the demands may vary according to the language proficiency of the learners. However, some teachers have favoured the incidental way of teaching while others tended to lean on the direction of explicit teaching of vocabulary. The teachers also favoured integrating the teaching of vocabulary into teaching grammar and other material (e.g. culture) rather than having separate teaching sessions, although few used them too. All teachers followed more or less the same route when it came to question of different phases in vocabulary teaching, namely the three C's presented in Pavivic Takac (2008) were present.

Furthermore, the advantages of vocabulary learning outside the classroom should be investigated more by the teachers in addition to acknowledging it inside the classroom. The teachers generally 
Elhamdi, O. E. H., \& Hezam, A. M. M. (2020) Challenges for Methods of Teaching English Vocabulary to Non-native Students. Advances in Social Sciences Research Journal, 7(5) 556-575.

though their students do study/acquire vocabulary outside the classroom too but were unsure how useful it was. The main sources for vocabulary outside of the classroom were thought to be those from popular culture, namely movies, games and TV. Curiously, social media was not deemed as important at this point although many young learners spend a lot of time on social media on a daily basis (Lenhart 2015).

\section{Previous Studies \\ Study one}

Farjami, Fahime. (2013). Analysis of the Impediments to English Vocabulary Learning and Teaching. International Journal of Language and Linguistics.

Learning a foreign or second language at different levels of proficiency involves the acquisition of a great number of words. Language learners look for effective ways to increase opportunities for retaining new words in long-term memory, but forgetting is a common problem. Language learners often complain that they forget new words soon. The importance of vocabulary learning also poses some challenges for teachers. They like to know in what ways instructional programs might foster the acquisition of so many words. Students face some barriers when they try to assign the vocabularies to their long-term memories. In this paper, learners' problems in vocabulary learning are elaborated on and some guidelines are offered to ameliorate or even to remove them. In so doing, it introduces language learning strategies that make vocabulary learning interesting and easy for learners. It also familiarizes teachers with useful techniques and activities for presentation. Ideas and viewpoints put forward by distinguished scholars in this area will be utilized to substantiate the arguments. The purpose of this study is to present practical vocabulary learning strategies that can help learners and to offer influential teaching techniques and activities, which are of help to the teachers.

\section{Study Two}

Difficulties in English Vocabulary Learning Experienced by The Eighth Grade Students of SMP Negeri I Borobudur In the Academic Year Of 2011/2012 by Nunik Rahmawati, (Ph D Thesis).

This study is intended to find out the difficulties in English Vocabulary learning among the eighth grade students of SMP Negeri I Borobudur in the Academic Year of 2011/2012. The research used descriptive quantitative method because the researcher described the data in the form of number. The researcher also used descriptive qualitative method to help the quantitative explanation. The population of this research is all the eighth grade students of SMP Negeri I Borobudur in the academic year of 2011/2012 which is divided into 7 classes that are 222 students. The researcher took 32 students as the sample. To collect the data, the researcher used a test as the instruments. The test consisted of vocabulary mastery and it contained 40 items in the form of multiple choices. After that the researcher tried to find the item difficulties of each item to reflect the difficulty of the test. In analyzing the data, the researcher used descriptive analyses which deal with the ideal mean, ideal standard deviation, maximum score, minimum score, the possible maximum score, and categorization. The researcher also used descriptive method since the data which are described in the form of sentences that are the difficulties faced by the students in vocabulary learning, the possible caused of those difficulties and some solutions to solve those difficulties. The result shows that the mean score was 15.59 with a standard deviation of 3.164. Meanwhile, the maximum score is 22 and the minimum score was 7 and the possible maximum score was 30 . After being consulted 
with the ideal mean and ideal standard deviation, it can be concluded that the students" mastery in vocabulary can be categorized into poor category. The students still have difficulties when they do the test. The less serious difficulties of vocabulary learning faced by the students are the meaning, pronunciation, and use of words. The other aspect of words is categorized into least serious is spelling.

\section{Study Three}

Hosain, Amir. (2018). Difficulties of Learning English Language at the Secondary Level: A Case Study of Thakurgaon District. Journal of Education and Training. 5. 165. 10.5296/jet.v5i2.13500.

The aim of this paper is to examine the complexities of learning English Language among the SSC level learners of Lahiri High School under Thakurgaon District, a northern part of Bangladesh. Many students don't receive Standard Education of English due to knowledgeable teachers, financial constraints, lack of multimedia project teaching and learning system, and lack of English Language Club. It aims to look at motivating the young learners so that they can be able to develop the basic knowledge of four skills despite depriving of ultra-modern facilities. For this purpose, the current researcher collected date through questionnaire and interview process. 15 sets of questions were provided among 15 students to find out their fundamental knowledge of English language. In the field survey, 31 participants were selected for interview, including 15 male \& female students, 6 teachers, and 10 guardians. Teachers and parents expressed their different views about English language learning complexities. Participants responded that students were weak in English Grammar, Vocabulary, and Speaking Skill. After realizing their English learning complexities, the researcher came to conclusion and recommendations. Thus, this study would like to show a new dimension of English Language Learning for the Secondary Level students at Thakurgaon District in Bangladesh.

\section{Study Four}

Dessalegn Oljira, (2015) A Study on Problems of Vocabulary Teaching Techniques English Teachers Use in Holeta Primary Schools: Grade Seven in Focus

In this research, an effort was made to study problems of vocabulary teaching techniques English teachers use in Holeta Primary school. To carry out the study both quantitative and qualitative research designs were used. For choosing the representative sample of the students participating to the study, two stage sampling technique was used to manage the large population size in the schools under the study. Then the study participants were chosen through simple random sampling techniques. The instruments employed to gather data were questionnaire and classroom observation. Close ended questionnaires were prepared for both teachers and students. In addition to this tool, actual classroom observation was also used to gather data. To make an observation meaningful, manageable and avoid confusion, an observation check list was prepared. Thus, randomly chosen sections in each school were observed three times while the actual teaching/learning process of the target language skills was conducted. After the data gathered from questionnaire was tabulated and analyzed in percentage, it was triangulated with data gathered from classroom observation. Finally the following conclusions were made: vocabulary teaching was given little emphasis(both learners' and teachers' awareness to classroom vocabulary teaching /learning was relatively poor), teaching techniques that teachers used to teach learners does not seem to be successful in enhancing students' vocabulary use (less effective in encouraging them to 
Elhamdi, O. E. H., \& Hezam, A. M. M. (2020) Challenges for Methods of Teaching English Vocabulary to Non-native Students. Advances in Social Sciences Research Journal, 7(5) 556-575.

do more on vocabulary activities in English classes), students were waiting for teachers' translation of vocabulary in to their vernacular language (L1), students and teachers' awareness on the importance of carrying out vocabulary activities in class through the contextual clue were low, teachers didn't help students to become empowered in the classroom and feel confident spontaneously to participate in different vocabulary activities and motivate them to feel confident and risk takers. The study also revealed that ineffective grouping of students during vocabulary learning influence learners' vocabulary use and development because students feel less capable of participating in class when they were exposed to small groups,, teachers didn't develop awareness on eliciting some vocabularies which enhance learners' motivation during vocabulary teaching learning in the class, teachers didn't make the instruction clear to initiate and avoid confusion of learners while they request them to work on vocabulary tasks. Generally, teacher's lack of continuous professional training on teaching methodology has a great impact for problems observed in the class.

\section{Study Five}

Asghar Ali Ansari. Teaching of English to Arab Students: Problems and Remedies Umm -al Quara University, University College, Makkah, Saudi Arabia Accepted 20 April, 2012. Educational Research (ISSN: 2141-5161) Vol. 3(6) pp. 519-524, June 2012

Because of the social and cultural backgrounds of his students a teacher of English faces a lot of problems while teaching English to Arab students especially in Saudi Arabia. There are many reasons for this. The first and the most important reason is that the Arab students have no knowledge of even basic English although they are taught English in schools. Perhaps the school teachers do not pay proper attention towards the teaching of English. Whatever may be the reason for this but the teacher who teaches those students in higher classes suffers the most and faces a lot of problems while teaching them a prescribed book or course in higher classes. On the other hand, students look towards their teacher with great hope. They consider the teacher the most competent and think that their teacher would make them learn English very soon Thus a teacher's responsibility towards his students is doubled. As a result, many English teachers are fade up and disappointed and so leave the assignment in the middle of their contract. But if the teacher has a little patience and is competent and intelligent, he would handle the situation easily and achieve his goal. The plans, strategies and methods of teaching English to these students have been discussed in details in the main research paper.

\section{Study Six}

Ahmed Sulaiman Al-Nasser, Problems of English Language Acquisition in Saudi Arabia: An Exploratory-cum-remedial Study College of Science and Arts, Methnab, Qassim University, Saudi Arabia

'An international language belongs to its users, not to the countries whose national languages have become internationalized' (Edge 1992). With an ever-increasing number of L2 users it is time we rewrote the description of the place of English among world languages. All types of interactions, more particularly between nations, are through English, for a reason no other than the fact that it is the only language in which non native users can possibly communicate. It is the language of science, technology and business apart from being significant in political or diplomatic dialogues. English Language has come to be owned by all people in the world of work. Saudi Arabia is no exception. 
Almost a hundred years on Saudi schools, colleges and universities teach English with primary and genuine concern. Still, just like non- native learners in other non-English speaking countries, Saudi learners also confront many problems in their English Language acquisition. This study is a humble effort to bring out the major barriers and problems that Saudi students face while learning English; it proposes remedial measures for the said barriers and problems. In this study, the researcher has tried to focus on the teaching methodologies and learning atmosphere prevalent in Saudi English classrooms.

\section{Study Seven}

Rababah, Ghaleb, Communication Problems Facing Arab Learners of English.

This paper discusses problems faced by Arab learners of English in general, focusing on problems specific to English language majors/graduates at Arab World University. It highlights the situation with Jordanian students, noting various causes of their problems with English (e.g., school and English language department curricula, teaching methodology, lack of exposure to the target language in language teaching, lack of exposure to the target language as spoken by native speakers, and student attitudes and motivation). The paper discusses the notion of communicative competence, in particular strategic competence, and its relationship with language teaching as it leads to learning. It defines strategic competence (the ability to use communication strategies to get a message across and compensate for limited knowledge of rules of the language), explains communication strategies (which are employed when the second language speaker encounters a problem in communication), and looks at taxonomies of communication strategies. The paper discusses how the use of communication strategies leads to learning and concludes with the pedagogical implications of using

\section{Study Eight}

Nurullah Mansourzadeh, A Comparative Study of Teaching Vocabulary through Pictures and Audiovisual Aids to Young Iranian EFL Learners

The purpose of the present study was to compare two techniques of teaching vocabulary to young Iranian EFL learners, namely still pictures and audio-visual aids, to find out if any of them was more effective than the other. In other words, this study was designed to seek answer to the following question: Are audiovisual aids more effective than still pictures on learning vocabulary by young Iranian EFL learners? In order to answer the above question, two classes, each consisting of $30 \mathrm{EFL}$ beginner learners, were randomly selected among 128 students learning EFL in grade two at Imam Hossein guidance school in Zahedan, Iran. Since both groups were homogeneous, the vocabulary test (pre-test) was given to the participants at the outset of the study. One group received its instruction through audiovisual aids for teaching vocabulary while the other group was taught through still pictures. After ten sessions of instruction, the post-test (achievement test) was administered to both groups to see the effect of both instructional techniques. The obtained results through descriptive statistics (mean and standard deviation) indicated there was a significant difference between the group which was taught through pictures and the one which received audiovisual aids. In other words, using pictures was more effective than audio-visual aids in teaching vocabulary to Iranian EFL beginners. Thus, the null hypothesis was rejected and some recommendations are given at the end. 
Elhamdi, O. E. H., \& Hezam, A. M. M. (2020) Challenges for Methods of Teaching English Vocabulary to Non-native Students. Advances in Social Sciences Research Journal, 7(5) 556-575.

\section{Study Nine}

Teaching Vocabulary Using Flashcards and Word List, Elsa Yusrika Sitompul. English Education Study Program of Indonesia University of Education

The study was conducted to investigate the effect of using flashcards or word list on fifty graders' vocabulary mastery and to discover the students' responses toward both strategies in learning English vocabulary. This study employed a quasi-experimental research design which involved two classes, grouped into experimental and control groups with a relatively similar vocabulary mastery before treatment. The experimental group received flashcards treatment while the control group received word list treatment. The results showed that students' vocabulary mastery improved after they were taught by using flashcards and wordlist. The students in experimental group admitted that they could memorize the words easily, be more motivated to learn English and understand vocabulary easily. On the other hand, students in the control group perceived that word list was a tedious strategy. Hence, it was concluded that flashcards are recommended to teach vocabulary to young learners.

\section{Study Ten}

Mahmoud Sultan Nafa, (2013). A Brain Based Approach for Teaching English Language Vocabulary to ESL Learners : An Investigation Based on Arabic-speaking Learners.

This dissertation focuses on the low attainment of L2, second language, vocabulary acquisition by grade 12 Arab learners of English studying at a public secondary school in Dubai. Learning vocabulary is the core of teaching and learning foreign languages as learners cannot fully master the L2 skills such as listening, speaking, reading and writing without having a highly advanced lexical competence. Accordingly, this dissertation implements the brain based approaches and strategies in order to enrich L2 vocabulary teaching and learning processes. In addition, it adopts the mixed research method that is the use of both the quantitative and the qualitative approaches for exploring the problem of the students' L2 vocabulary low attainment by grade 12 Arab learners at Al- Maarif Secondary School in Dubai. Therefore, the findings and the recommendations of this dissertation have a practical pedagogical importance as they present practical brain-based teaching methodologies that enhance the teachers' and the learners' experiences of teaching and learning L2 vocabulary. To conclude, the key findings and the empirical studies of this study show that the brain-based approach is proved to be effective in treating the problem of L2 vocabulary low attainment. Markedness has also been proven to be a useful analytic tool in analyzing the current situation of teaching and learning L2 Vocabulary. Thus, the recommendations of this dissertation can be implemented on all ELS students all over the world due to the universality and the practicality of the brain-based approaches and the markedness framework.

\section{Study Eleven}

Teaching Vocabulary in the Primary Grades: Vocabulary Instruction Needed. Andrew Biemiller, Institute of Child Study, Ontario Institute for Studies in Education at the University of Toronto

Vocabulary is a powerful predictor and correlate of reading comprehension, and consequently of academic success. By the end of the grade two, children in the highest quartile know twice as many words as children in the lowest quartile. Schools have done little to change this outcome during the primary grades, where there is little attention to vocabulary. Unless primary grade children with 
low vocabularies have a chance to build vocabulary in school, they will continue to lag seriously behind more advantaged children. It is possible to identify high priority word meanings that are known by those with large vocabularies, but not known by those with small vocabularies. There is also a good evidence that low-vocabulary children can learn needed words from classroom instruction. Teachers can assess how well taught vocabulary is learned by a class of primary grade children. In short, needed vocabulary can be taught and assessed in primary grades.

\section{Study Eleven}

Using Games as a Tool in Teaching Vocabulary to Young Learners Sahar Ameer Bakhsh, Sahar Ameer Bakhsh, English Language Institute, King Abdul Aziz University, Jeddah, KSA.

Over the last few decades, teaching English become a phenomenon in Saudi Arabia, especially to young learners. English is taught as a main subject in kindergarten and elementary schools. Like any other children, Saudis accept new foreign languages easily, but they get bored very fast if the teacher is teaching them using the old conventional methods and techniques. The aim of this paper is to prove that games are effective tools when devised to explain vocabularies and they make it easier to remember their meanings. This paper deals with a literature review of teaching English vocabulary to young learners using games. Then it discusses the importance of using games in teaching vocabulary and in what way using them is helpful. After that it investigates the practical implications of using games to teach vocabulary that includes the implementation of vocabulary games and some examples of games that could be used to teach vocabulary to children. And finally, it examines challenges teachers face when teaching vocabulary using games to young learners.

\section{Study Twelve}

The Impact of WhatsApp on EFL students' Vocabulary Learning

Elias Bensalem Languages and Translation Department Northern Borders University Arar, Saudi Arabia

Social networking applications have emerged as potential new tools for enhancing second language vocabulary learning. The current study explores the development of academic vocabulary knowledge of English as a foreign language (EFL) students using WhatsApp compared to the traditional method of vocabulary instruction. It also aims at investigating students' perceptions about the use WhatsApp in learning vocabulary. Forty Arab EFL students at the elementary level enrolled at a public university in the Arabian Gulf region participated in the study. Twenty-one participants belonging to the same class were randomly assigned to the experimental group. They completed and submitted their vocabulary assignments which consisted of looking up the meanings of new words in a dictionary and building a sentence using each word and submitting their sentences via WhatsApp. Nineteen students from another class were assigned to the control group. They had to submit the same homework assignment using the paper and pencil method. Data were collected using pretest-posttest design. Results of t-test scores indicated that WhatsApp group significantly outperformed the traditional group on a vocabulary test. Furthermore, results of a questionnaire that gauged participants' perception of the use of WhatsApp in learning vocabulary show that generally participants have positive attitudes towards learning new vocabulary items via WhatsApp. Implications for teaching and future research are discussed. 
Elhamdi, O. E. H., \& Hezam, A. M. M. (2020) Challenges for Methods of Teaching English Vocabulary to Non-native Students. Advances in Social Sciences Research Journal, 7(5) 556-575.

\section{Study thirteen}

Sadiq A.A. I, et al (2010) Teachers' perceptions of the use of technology in teaching languages in United Arab Emirates' schools.

The purpose of this study was to investigate the perceptions of both teachers of Arabic and teachers of English about the use of technology in their classes in United Arab Emirates" (UAE) schools. The success of integrating instructional technology in teaching and learning languages depends heavily on the attitude and support of the teachers involved, so a questionnaire and a focus group-interview technique were used to collect the data from teachers. Descriptive statistics and t-tests were used to analyze the questionnaire data, while focus group data were thematically analyzed. Results obtained from both the quantitative and qualitative data revealed teachers" perceptions about integrating technology in their classes, barriers to technology use, incentives for teachers who use technology, types of technology used, and their own and students" use of technology. This paper concludes with recommendations to facilitate the use of technology in teaching languages in the UAE.

\section{Study fourteen}

Bridging the Gap between Receptive and Productive Vocabulary Size through Extensive Reading. Yuka (Maruyama) Yamamoto Toyo Eiwa University

It is well established that extensive reading promotes the incidental learning of $\mathrm{L} 1$ and $\mathrm{L} 2$ receptive vocabulary; however, little is known about its effectiveness on productive gains in vocabulary knowledge. This paper investigates the extent to which extensive reading combined with writing tasks promotes productive vocabulary growth of Japanese university students. To examine changes in vocabulary size, three tests were administered: The Vocabulary Levels Test (Nation, 1990), the Productive Vocabulary Levels Test (Laufer \& Nation, 1999), and the VocabProfile (Cobb, 2010). Contrary to expectations, no significant increase was shown in the amount of productive vocabulary size. However, the data suggested that one of the benefits of doing extensive reading with writing tasks is to retain receptive and productive vocabulary knowledge

\section{Study fifteen}

Intakhab Alam Khan, (2011). Learning difficulties in English: Diagnosis and pedagogy in Saudi Arabia King AbdulAziz University Community College.

Teaching of English as a Foreign Language is always a challenging task. English in Saudi Arabia serves a very limited purpose. Yet, it is very important for social as well as technological development. Therefore, English language teaching in this country in particular catches attention of many researchers. Teaching of English in Saudi starts at the school level. Despite good overall planning, purposive curriculum, integrated textbooks, qualified teachers, achievement is below the expectations. Therefore, diagnostic studies should better be undertaken in different language areas and skills so that the teacher may know the types of the problems and the corresponding factors. Such attempts are expected to be helpful in possible evolution of some fruitful and compatible strategies in order to yield the maximum academic output. Pedagogues have different views regarding English Language Teaching which may occasionally involve translation from First language to the target language and vice versa. On the other hand, the idea of Communicative 
approach to Language Teaching (CALT) is also significant in order to focus the skills. However, Bilingual approach can also be used as an alternative strategy.

\section{Study sixteen}

Mu-hsuan Chou (2014) Assessing English vocabulary and enhancing young English as a Foreign Language (EFL) learners' motivation through games, songs, and stories.

In Taiwan, English was only officially taught at the secondary and tertiary levels before 2001. Since 2001, English courses have been formally incorporated into the curriculum in primary schools. Research on teaching and assessing English in primary school education is relatively new compared with research on other levels of education in Taiwan. The present study investigated the degree to which games, songs, and stories helped increase primary school pupils' English vocabulary size and encouraged learning in an intensive English course. It also explored how different test techniques influenced pupils' performance on a vocabulary test. Seventy-two primary school pupils participated in the study. The results showed that games, songs, and stories had a positive effect on learning and increasing the pupils' English vocabulary. In the vocabulary test, the pupils in higher grades outperformed those in lower grades and performed differently in terms of test techniques.

\section{Study Seventeen}

Rakchanok Saengpakdeejit (2014) Strategies for Dealing with Vocabulary Learning Problems by Thai University Students Faculty of Liberal Arts, Khon Kaen University, Nong Khai Campus, Nong Khai, Thailand.

Nowadays, vocabulary learning plays an important role in language teaching especially in the context where English is taught as a foreign language. This is because lexical competence is now seen as the heart of language learning and the ultimate goal of language teaching is to improve the language competence of learners. Additionally, vocabulary has been recognized as an important factor for language learning because insufficient vocabulary knowledge leads the learners to encounter difficulties in language learning. Learners can significantly improve their language competence by developing their ability to use vocabulary learning strategies (VLSs). The present study primarily aimed at investigating how Thai university students deal with vocabulary problems. The participants were 63 undergraduate students studying at Khon Kaen University. A semistructured interview was used as a method of data collection. After completing the stage of data collection, the interview recordings were transcribed verbatim and then translated from Thai into English for the purpose of data analysis. The translated data was then validated and analyzed. Under the constraint of language learning, the results show two main purposes in employing strategies for dealing with vocabulary learning problems: 1) to discover the meaning of unknown words; and 2) to retain the newly learned words in long-term memory and recall them at will. Furthermore, the data indicated that there are three groups of strategies employed for discovering the meaning of new words, i.e. Discovery, Social, and Support strategies, and the other three groups of strategies for retaining and recalling new words, i.e. Memory, Cognitive, and Metacognitive strategies.

\section{Study Eighteen}

Rahmawati, Irma (2015) Problems in Teaching Vocabulary to Young Learners at Aisyiyah Bustanul Athfal 01 Kindergarten Malang. Other thesis, University of Muhammadiyah Malang. 
Elhamdi, O. E. H., \& Hezam, A. M. M. (2020) Challenges for Methods of Teaching English Vocabulary to Non-native Students. Advances in Social Sciences Research Journal, 7(5) 556-575.

In vocabulary teaching learning process, the teachers might get some problems. The problems in teaching vocabulary were divided into two: the linguistic and the nonlinguistic problems. The writer conducted this research to investigate the teachers $\hat{A}^{\prime}$ problems in teaching vocabulary and the way to solve the problems. In this case, the writer used descriptive qualitative research design and used semi structured interview and non-participant observation to collect the data. The objects of this study were two teachers who taught in class A and B at Aisyiyah Bustanul Athfal 01 Kindergarten Malang. After collecting data from the subject of study, the researcher continues to analyze the data through some steps: a) Matching the data from the interviewÂ's result and the observation, $b$ ) Classifying the problems in teaching vocabulary to young learners and the way to solve the problems based on the research problems, c) Drawing conclusion based on the results of the data that had been analyzed. The result of the study indicated the problems covered both the linguistic and the non- linguistic problems. From the linguistic aspect, the problems faced by the teachers in teaching vocabulary were about pronunciation, grammar, vocabulary mastery, and dialect. Meanwhile, the nonlinguistic problems included studentÂ's ability, behavior and motivation, teacherÂ's educational background, limited material and media, monotonous methods, society support, and limited time. There were many solutions done to solve teacherÂ's problems in teaching vocabulary to young learners. From linguistic problems, the teachers practiced pronouncing certain words, shared with their friends, looked up the EnglishÂ's book guide for teacher of young learners, practiced English regularly, used dictionary, and practiced their dialect. In solving nonlinguistic problems, teachers used interesting methods and more media, games, pictures, reading stories and gave more attention to their students. To build parentÂ's involvement, teachers tried to call parents and invited them to visit the class to see their childÂ's learning, gave more attention especially to the silent student to increase student $\hat{A}$ 's motivation in learning vocabulary.

\section{CONCLUSION}

Finally, the researchers have come to the challenges after having a very soft landing to the main topic of this research, which is the challenges of teaching methods of English vocabulary to nonnative students, and presenting a conceptual coverage of certain areas that are relevant to English vocabulary teaching / learning. The conceptual coverage includes: the definition of the term vocabulary, kinds of vocabulary, the importance of vocabulary, general principles for successful vocabulary teaching, teaching vocabulary in the English as a foreign language (EFL) context challenging, techniques of teaching vocabulary, and the need for teaching vocabulary. The challenges basically, obtained from survey of a huge number of previous studies and covering of the relevant literature according to the qualitative method.

Finally, the challenges that are critically obtained by the researchers can be classified into three main categories. The first category, challenges related to students, the second one, challenges related to teachers, and the third one, challenges related to methods/ techniques/ strategies of teaching vocabulary. These three categories can be separately explained into points, one by one.

\section{Challenges related to students}

1. Language learners often complain that they forget new words soon.

2. Students face some barriers when they try to assign the vocabularies to their long-term memories.

3. The students still have difficulties when they do the test. 
4. Many students don't receive Standard Education of English due to knowledgeable teachers, financial constraints, lack of multimedia project teaching and learning system, and lack of English Language Club. So, the challenge is to look at motivating the young learners so that they can be able to develop the basic knowledge of four skills despite depriving of ultramodern facilities.

5. Students are waiting for teachers' translation of vocabulary in to their vernacular language (L1).

6. The first and the most important challenge is that the Arab students have no knowledge of even basic English although they are taught English in schools.

7. Students look towards their teacher with great hope. They consider the teacher the most competent and think that their teacher would make them learn English very soon.

8. The ability to use communication strategies to get a message across and compensate for limited knowledge of rules of the language.

9. Students get bored very fast if the teacher is teaching them using the old conventional methods and techniques.

\section{Challenges related to teachers}

1. The importance of vocabulary learning also poses some challenges for teachers. They like to know in what ways instructional programs might foster the acquisition of so many words.

2. following useful techniques and activities for vocabulary presentation.

3. Teachers don't help students to become empowered in the classroom and feel confident spontaneously to participate in different vocabulary activities and motivate them to feel confident and risk takers.

4. Teachers don't develop awareness on eliciting some vocabularies which enhance learners' motivation during vocabulary teaching learning in the class.

5. Teachers don't make the instruction clear to initiate and avoid confusion of learners while they request them to work on vocabulary tasks.

6. Generally, teacher's lack of continuous professional training on teaching methodology has a great impact for problems observed in the class.

7. Perhaps the school teachers do not pay proper attention towards the teaching of English.

8. The teacher should have a little patience and should be competent and intelligent he would handle the situation easily and achieve his goal.

9. Discovering the students' responses toward strategies in learning/teaching English vocabulary.

10. Treating the problem of L2 vocabulary low attainment.

11. Teachers can assess how well taught vocabulary is learned by a class of primary grade children.

\section{Challenges related to methods/ techniques/ strategies of teaching vocabulary}

1. Language learning strategies that make vocabulary learning interesting and easy for learners, which can help learners and offer influential teaching techniques and activities, which are of help to the teachers.

2. Vocabulary teaching was given little emphasis(both learners' and teachers' awareness to classroom vocabulary teaching/learning was relatively poor), teaching techniques that teachers used to teach learners does not seem to be successful in enhancing students' 
Elhamdi, O. E. H., \& Hezam, A. M. M. (2020) Challenges for Methods of Teaching English Vocabulary to Non-native Students. Advances in Social Sciences Research Journal, 7(5) 556-575.

vocabulary use (less effective in encouraging them to do more on vocabulary activities in English classes).

3. Students and teachers' awareness on the importance of carrying out vocabulary activities in class through the contextual clue were low.

4. The study also revealed that ineffective grouping of students during vocabulary learning influence learners' vocabulary use and development because students feel less capable of participating in class when they were exposed to small groups.

5. The teaching methodologies and learning atmosphere.

6. School and English language department curricula, teaching methodology, lack of exposure to the target language in language teaching, lack of exposure to the target language as spoken by native speakers, and student attitudes and motivation.

7. Using pictures and audio-visual aids in effectively in teaching vocabulary.

8. Teaching/Learning vocabulary is the core of teaching and learning foreign languages as learners cannot fully master the L2 skills such as listening, speaking, reading and writing without having a highly advanced lexical competence.

9. Vocabulary is a powerful predictor and correlate of reading comprehension, and consequently of academic success.

10. The importance of using games in teaching vocabulary and in what way using them is helpful.

11. The success of integrating instructional technology in teaching and learning languages, and facilitating the use of technology in teaching languages

12. Bridging the Gap between Receptive and Productive Vocabulary Size through Extensive Reading

13. Possible evolution of some fruitful and compatible strategies in order to yield the maximum academic output.

14. The degree to which games, songs, and stories help increase primary school pupils' English vocabulary size and encourage learning in an intensive English course.

15. Exploring how different test techniques influence learners' performance on a vocabulary test.

16. Developing strategies for discovering the meaning of unknown words.

17. The linguistic aspect challenge, when teaching vocabulary: pronunciation, grammar, vocabulary mastery, and dialect.

18. The nonlinguistic challenge when teaching vocabulary: learners' ability, behavior and motivation, educational background, limited material and media, monotonous methods, society support, and limited time.

19. Building parents involvement.

\section{References}

Allen, Virginia French. Techniques in Teaching Vocabulary. New York: Oxford UP, 1983.

Anna, S., Stuart, W., (2016)Teaching Vocabulary in the EFL Context In book: English Language Teaching Today (pp.227-239). Springer DOI: 10.1007/978-3-319-38834-2_16

Bensalem, E. (2018). The Impact of WhatsApp on EFL students' Vocabulary Learning. Arab World English Journal, 9 (1). DOI: https://dx.doi.org/10.24093/awej/vol9no1.2

Dessalegn Oljira, (2015) A Study on Problems of Vocabulary Teaching Techniques English Teachers Use in Holeta Primary Schools: Grade Seven in Focus International Journal of Science and Research (IJSR) ISSN (Online): 23197064 Index Copernicus Value (2015): 78.96 
Diamond and Gutlohn (2006) in www.readingrockets.org/article

Gairns, R. \& Redman, S. (1986). Working with words: A guide to teaching and learning vocabulary. USA: Cambridge University Press.

Harmer, Jeremy: The Practice of English Language teaching, Longman, 1993.

Hornby (1995) International Journal of Teaching and Education Vol. III, No. 3 / 201524.

Intakhab Alam Khan, (2011). Learning difficulties in English: Diagnosis and pedagogy in Saudi Arabia King AbdulAziz University Community College. Educational Research (ISSN: 2141-5161) Vol. 2(7) pp. 1248-1257 July 2011

International Journal of Teaching and Education Vol. III, No. 3 / 201527

International Journal of Teaching and Education Vol. III, No. 3 / 201528

K. Hammarberg, M. Kirkman, S. de Lacey. Qualitative research methods: when to use them and how to judge them. Human Reproduction, Volume 31, Issue 3, March 2016, Pages 498-501, https://doi.org/10.1093/humrep/dev334.

Laufer, B. \& P. Nation. (1999). A vocabulary size test of controlled productive ability. Language Testing 16, $33-51$

Lenhart, A. (2015) Teens, Technology and Friendships. Pew Research Center. [online]. http://www.pewinternet.org/2015/08/06/teens-technology-and-friendships/. (12th April 2016).

Melka, F. (1997). Receptive vs. productive aspects of vocabulary. In Schmitt, N. and McCarthy, M. (eds.) Vocabulary: Description, acquisition and pedagogy. Cambridge: Cambridge U.P., 84-102.

Mu-hsuan Chou (2014) Assessing English vocabulary and enhancing young English as a Foreign Language (EFL) learners' motivation through games, songs, and stories, Education 3-13, 42:3, 284-297, DOI:

10.1080/03004279.2012.680899

Nation, I. S. P. (1990). Teaching and learning vocabulary. Boston: Heinle \& Heinle

Nation, I. S. P. (1990). Teaching and learning vocabulary. Boston, Mass.: Heinle\&Heinle Publishers.

Nation, P. (2001). Learning vocabulary in another language. Cambridge: Cambridge University Press.

Pavičić Takač, V. (2008). Vocabulary learning strategies and foreign language acquisition. Clevedon: Multilingual Matters.

Rahmawati, Irma (2015) Problems in Teaching Vocabulary to Young Learners at Aisyiyah Bustanul Athfal 01 Kindergarten Malang. Other thesis, University of Muhammadiyah Malang.

Rakchanok Saengpakdeejit, (2014). Strategies for Dealing with Vocabulary Learning Problems by Thai University Students Faculty of Liberal Arts, Khon Kaen University, Nong Khai Campus, Nong Khai, Thailand. Silpakorn University Journal of Social Sciences, Humanities, and Arts Vol.14(1) : 147-167, 2014

Sadiq A. A. I, et al. Teachers' perceptions of the use of technology in teaching languages in United Arab Emirates' schools. International Journal for Research in Education (IJRE), NO. 27, 2010.

Sagmiller, K. M. (2002, October). Supporting the development of an effective teacher. Paper presented at the 2nd Annual Teacher Institute, Southern Oregon University, Ashland, OR.

Schmitt, N. (2010a) Key Issues in Teaching and Learning Vocabulary.

Schmitt, N. (2010b). Researching vocabulary: A vocabulary research manual. Houndmills, Basingstoke, Hampshire; New York: Palgrave Macmillan.

Wallace Michael: Practical Language Teaching, Teaching Vocabulary, Heinemann, 1988 